\title{
Analysis of methodologies for determination of the economic pipe diameter
}

\author{
Análise de metodologias para determinação do diâmetro econômico de adutoras
}

\author{
Cléber Henrique de Araújo Gama ${ }^{1}$ (D), Vladimir Caramori Borges de Souza ${ }^{2}$ (D) and Nélia Henriques Callado (D) $^{\circ}$ \\ ${ }^{1}$ Instituto de Pesquisas Hidráulicas, Universidade Federal do Rio Grande do Sul, Porto Alegre, RS, Brasil \\ ${ }^{2}$ Universidade Federal de Alagoas, Maceió, AL, Brasil \\ E-mails: cleber.hag@gmail.com (CHAG),vcaramori@yahoo.com (VCBS), nelia.callado@yahoo.com.br (NHC)
}

Received: August 29, 2018 - Revised: May 13, 2019 - Accepted: June 18, 2019

\begin{abstract}
The design of water distribution systems includes, above all, the determination of the pipe size that meets the requirements of the system and brings reduced annual costs of installation and operation. Among the existing methodologies for the economic pipe diameter determination, Bresse's equation is still common among designers. This work aims to analyze the efficiency of Bresse's equation, the MBPW and the MLVPC, comparing them with the MREC. We recommend that the designers do not use the MBPW and the MLVPC. When referring to water distribution systems of small size, it is possible to use the equation of Bresse, as long as it is used with a proper value for its coefficient $k$. For HDPE, we propose $k=1.17$ or $k=1.18$. For PVC DEFOFO and GFRP, we suggest the range of 1.19 to 1.23 and 1.29 to 1.32 , respectively. Regarding the water distribution systems of bigger dimensions, we recommend the use of MREC as the methodology for the economic pipe diameter determination, due to the impossibility of finding an appropriate value for the Bresse's equation coefficient.
\end{abstract}

Keywords: Economic pipe diameter; Bresse's equation; Water distribution systems design.

\section{RESUMO}

O dimensionamento de sistemas adutores passa, sobretudo, pela determinação de um diâmetro que atenda às necessidades do sistema e acarrete em menores custos anuais de instalação e operação. Dentre as metodologias existentes para determinação do diâmetro econômico, a Fórmula de Bresse ainda é comum entre projetistas. Este trabalho teve como objetivo analisar a eficiência da Fórmula de Bresse, do MBPC e do MVLCT, comparando com o Método da Avaliação Real dos Custos. Ao fim deste trabalho, recomenda-se que o MBPC e o MVLCT não sejam utilizados pelos projetistas. Quando tratar-se de adutoras de pequeno porte, é possível a utilização da Fórmula de Bresse, desde que seja utilizada com um valor adequado, variável em função do material, para o seu coeficiente $k$. Para o PEAD, propõe-se $k=1,17$ ou $k=1,18$. Para o PVC DEFOFO e PRFV, sugerem-se os intervalos de 1,19 a 1,23 e 1,29 a 1,32, respectivamente. Tratando-se de adutoras com dimensões maiores, recomenda-se a utilização do MARC como metodologia para determinação do diâmetro econômico, por não ser possível encontrar um valor apropriado ao coeficiente de Bresse.

Palavras-chave: Diâmetro econômico; Fórmula de Bresse; Dimensionamento de adutoras.

\section{INTRODUCTION}

Projects of water distribution systems are based on the determination of parameters - such as its extension and required flow rate - and appropriate dimensioning, in addition to the selection of materials that provide the highest efficiency. The appropriate dimensioning depends on the determination of water circulation's mean velocity, flow rate, pipe diameter and head loss in the system. Since flow rate is a parameter determined in the project, three parameters remain to be defined. However, there are only two equations are available for this task, the mass and energy conservation equations, which are functions of flow rate and pipe diameter, meaning the dimensioning is a hydraulically undetermined problem. 
The most appropriate dimensioning is based on definitions that assure the effectiveness of the system in complying with the requirements of the project and bring about economy in the installation and operational costs. The selection of small pipe diameters imply in lower installation costs but higher operational costs (especially due to higher electric consumption), since the installed power is a function of head loss (AZEVEDO NETTO; FERNÁNDEZ, 2015).

The methodology most commonly used in determining the economic pipe diameter is based on an equation proposed by Dupuit (1854) and adapted by Bresse (1860). For being old methodologies, with no recent updates, they are believed to be poorly dimensioning water distribution systems, resulting in unnecessary costs due to oversized pipe diameters. Thereby, it is important to study methodologies used in the determination of the economic pipe size, defined by Azevedo Netto and Fernández (2015) as the pipe diameter that results in the lowest total costs of installation and operation combined.

Dupuit (1854) proposed that the economic pipe diameter could be expressed by:

$$
D=k \sqrt{Q}
$$

where: $D$ is the economic pipe size; $k$ is a parameter that depends, among others, on the costs of the material, transportation, manhour, electric power, and system operation and maintenance; and $Q$ is the required flow rate. Dupuit suggested a value of 1.60 for $k$, based on the prices of coal, pipes, manpower and services at that time. Bresse then proposed a value of 1.50. Afterwards, a range of variation for this coefficient was proposed, considering that the prices of these items can vary according to the place of implementation and the material used in the system (TALAVERA, 2014).

Presently, Equation 1 is widely known as "Bresse's equation" and, in Brazil, the value of $k$ ranged from 0.9 to 1.4 between 1950 and 1970, assumed as 1.2 between 1980 and 1990, and from 2000 onwards its values have ranged from 0.6 to 1.5 (AZEVEDO NETTO; FERNÁNDEZ, 2015). Therefore, the range of values adopted for this coefficient have had a considerable variation, and this can be associated to increases in long-term total costs of these projects.

Other formulations have been proposed for the calculation of the economic pipe diameter, being the Method Based on Pipe Weight (MBPW) and the Method of the Linear Variation of Pipe Costs (MLVPC) the most known. However, the equation of Bresse is still usually employed and there are a few recent studies evaluating the variation of $k$, based on present prices of materials and services.

The Brazilian technical norm concerning projects of water distribution networks for public water supply - NBR 12218 does not recommend any methodologies for the dimensioning or determination of the economic pipe diameter. It only determines a range of velocities, from $0.6 \mathrm{~m} / \mathrm{s}$ to $3.5 \mathrm{~m} / \mathrm{s}$, that has to be observed by the water system designer (ABNT, 1994).

When applying the three aforementioned methodologies for the dimensioning of pipes of two water distribution systems in Paraíba, Freire (2000) verified that to dimension the diameters of these pipes using Bresse's equation would result in differences up to $300 \mathrm{~mm}$ from the pipe diameter that resulted in the lower costs.

Genić, Jaćimović and Genić (2012), analyzing the dimensioning of pipes made of different materials, such as cast iron, galvanized steel, carbon steel and iron pipes with asphalt coating, suggested that the economic pipe of should be determined using equations similar to Bresse's, but with a value of 0.89 for the coefficient $k$.

Guimarães (2009) simulated, based on real costs, the dimensioning of the economic pipe, made of RPVC, for 36 combinations of flow rate, pipe length and geometric height, and proposed that, for the conditions analyzed, the values of $k$ can range from 1.03 to 1.12 for this material. However, the author suggested that this study should be broadened for other project conditions and different materials.

Similarly, Bedjaoui, Achour and Bouziane (2005), applying other project conditions, suggested that fixing $k=1,27$ showed good results in the calculation of the economic pipe size made of PVC and HDPE.

At the same time, the increase in application of computational tools and easiness in estimating costs enable the determination of the economic pipe size using a method of real evaluation with less difficulty, in a way to make this method more advisable, when considering the cost increases due to the application of the other available methodologies.

In this sense, this study aims to evaluate methodologies to obtain the economic pipe diameter of water distribution systems, quantifying the cost differences associated to each method, and verifying the limitations that use of Bresse's equation brings about in present conditions.

\section{METHODOLOGIES FOR DETERMINATION OF THE ECONOMIC PIPE DIAMETER}

\section{Bresse's equation}

Bresse's equation (Equation 1) was one of the first equations for dimensioning pipes and it still is a common method among water system designers, which is likely due to its simplicity (FREIRE, 2000). Bresse's coefficient, $k$, is a parameter that depends on the costs of system operation and maintenance, manpower and electric power, among other factors.

The pipe diameter calculated by this equation is usually different than commercial diameters, making it necessary to select the closest commercial size. In fact, the application of Bresse's equation is equivalent to setting a "mean velocity", named "economic velocity” (AZEVEDO NETTO; FERNÁNDEZ, 2015).

\section{Method based on pipe weight}

Developed by Melzer (1964), it is based on the hypothesis that piping costs are proportional to its weight. The estimation of the piping weight is based on the hydraulic pressure over the pipes. The author concluded that the piping costs are proportional to the squared diameter and proposed the economic pipe diameter to be calculated by Equation 2, considering that the total costs of the water distribution system are composed of two parts: 
(i) costs of installation; and (ii) costs of operation. The resulting calculated pipe diameter needs then to be rounded to the closest commercial size.

$$
D=1.579 *\left(\frac{\beta * n * p}{C * a * \eta}\right)^{0.143} * Q^{0.43}
$$

where: $D$ is the pipe diameter, in meters; $Q$ is the required flow rate, in $\mathrm{m}^{3} / \mathrm{s} ; \beta$ is the Darcy-Weisbach roughness coefficient; $n$ are the hours of functioning of the pump and motor assembly, in hours/year; $p$ is the electric power cost, in $\mathrm{R} \$ / \mathrm{kWh}$; $C$ is the pipe cost per length per diameter, in $\mathrm{R} \$ / \mathrm{m}^{2} . \mathrm{m}$; $a$ is the coefficient of amortization, and here it was adopted as an interest rate of $12 \%$ per year, considering a lifetime of 20 years; $\eta$ is the efficiency of the pump motor assembly, ranging from 0 to 1 .

\section{Method of the linear variation of pipe costs}

This method, developed by Mendiluce (1966), is based on the premise that the piping costs vary linearly with diameter. As well as the previous methods presented, the resulting diameter has to be approximated to the closest commercial diameter. The author proposed that the economic pipe size can be determined by:

$$
D=1.913 *\left(\frac{\beta * n * p}{C * a * \eta}\right)^{0.166} * \sqrt{Q}
$$

where: $D$ is the pipe diameter, in meters; $Q$ is the required flow rate, in $\mathrm{m}^{3} / \mathrm{s} ; \beta$ is the Darcy-Weisbach roughness coefficient; $n$ are the hours of functioning of the pump and motor assembly, in hours/year; $p$ is the electric power cost, in $\mathrm{R} \$ / \mathrm{kWh} C$ is the pipe cost per length per diameter, in $\mathrm{R} \$ / \mathrm{m}^{2} \cdot \mathrm{m}$; $a$ is the coefficient of amortization, and here it was adopted as an interest rate of $12 \%$ per year, considering a lifetime of 20 years; $\eta$ is the efficiency of the pump motor assembly, ranging from 0 to 1 .

\section{Method of real evaluation of costs}

This method consists in determining the real costs of using commercial pipe diameters. The economic pipe diameter is the one whose total costs of energy consumption and yearly system implementation are the lowest. Therefore, the project costs are calculated for each commercial diameter and the one with lower cost, attending the project demands, is selected. Thus, this result in a selected economic pipe diameter that meets the commercial diameters available, and no approximation is needed. This procedure, while seemingly laborious, is easily implemented with the computational tools presently available.

According to Freire (2000), the economic pipe diameters must optimize the following equation:

$$
\left[P\left(D_{O T}\right)+M\left(D_{O T}\right)\right] * a * L+f * \frac{L}{D_{O T}} * \frac{8 * Q^{3}}{\pi^{2} * D_{O T}^{4} * \eta} * n * p=C_{\text {min }}
$$

where: $C_{\text {min }}$ is the minimal possible costs of the system, considering the available commercial pipe diameters; $D_{O T}$ is the economic diameters, in meters; $Q$ is the required flow rate, in $\mathrm{m}^{3} / \mathrm{s} ; P\left(D_{\text {OT }}\right)$ is a function of costs of purchase of materials, transportation and installation; $M\left(D_{O T}\right)$ is a function of the costs of earthworks; $a$ is the coefficient of amortization, and here it was adopted as an interest rate of $12 \%$ per year, considering a lifetime of 20 years; $L$ is the length of the system, in meters; $f$ is the pipe friction factor, which can be retrieved from Colebrook-White equation; $n$ are the hours of functioning of the pump and motor assembly, in hours/year; $p$ is the electric power cost, in $\mathrm{R} \$ / \mathrm{kWh} ; \eta$ is the efficiency of the pump motor assembly, ranging from 0 to 1 .

\section{METHODOLOGY}

\section{Definition of project conditions}

Project conditions are based on the characteristics of 20 real projects of water distribution systems. Flow rate and system size data were retrieved from private projects (ENGENHARQ, 1999; COHIDRO, 2016a,b,c,d,e), from applications discussed in Freire (2000) and public bidding processes from the Sanitation Company of Alagoas - CASAL (ALAGOAS, 2011, 2012, 2016). Flow rate values ranged from $0.558 \mathrm{l} / \mathrm{s}$ to $800 \mathrm{l} / \mathrm{s}$, and system size from $533 \mathrm{~m}$ to $45,400 \mathrm{~m}$.

The data inputted in the methods, representing each of these 20 projects, as seen in Table 1.

\section{Inputs and services accounted}

The prices of inputs and services used are based on the pricings on the Tabela SINAPI de Insumos e Serviços de (translated to SINAPI table of inputs and services) 06/2016, PCI.817-01, to the states of Alagoas (AL), Amazonas (AM), Rio Grande do Sul (RS), São Paulo (SP) and the Federal District (DF), in order to analyze one state in each Brazilian region.

Table 1. Project parameters, where Q is the project flow and L is the size of the system, in meters.

\begin{tabular}{ccc}
\hline & $\mathbf{Q}(\mathbf{1} / \mathbf{s})$ & $\mathbf{L}(\mathbf{m})$ \\
\hline $\mathbf{1}$ & 0.56 & 5780 \\
$\mathbf{2}$ & 2.92 & 2920 \\
$\mathbf{3}$ & 4.63 & 677 \\
$\mathbf{4}$ & 11.60 & 2598 \\
$\mathbf{5}$ & 12.90 & 2025 \\
$\mathbf{6}$ & 13.90 & 533 \\
$\mathbf{7}$ & 17.50 & 1230 \\
$\mathbf{8}$ & 19.00 & 5280 \\
$\mathbf{9}$ & 19.00 & 2238 \\
$\mathbf{1 0}$ & 20.00 & 7130 \\
$\mathbf{1 1}$ & 20.00 & 10000 \\
$\mathbf{1 2}$ & 21.90 & 1362 \\
$\mathbf{1 3}$ & 55.60 & 2522 \\
$\mathbf{1 4}$ & 210.00 & 2600 \\
$\mathbf{1 5}$ & 300.00 & 15059 \\
$\mathbf{1 6}$ & 315.00 & 4800 \\
$\mathbf{1 7}$ & 450.00 & 45400 \\
$\mathbf{1 8}$ & 600.00 & 45400 \\
$\mathbf{1 9}$ & 750.00 & 26590 \\
$\mathbf{2 0}$ & 800.00 & 45400 \\
\hline
\end{tabular}


The services accounted for in the calculation of the costs of installation of the water distribution systems are mechanical soil excavation (up to $3 \mathrm{~m}$ deep and $1.5 \mathrm{~m}$ wide), backfilling, earthwork send-off disposal and pipe laying. We considered that all systems were built underground and that the costs of excavation, backfilling and send-off disposal are based on the prices for soils of $1^{\text {st }}$ category in areas with low interference. As inputs, we considered the costs of pipe purchase. Regarding the costs with energy consumption, we considered the mean costs of water distribution systems in each state, available on ANEEL (2015), according to the Resolution 1984 (translated from Resolução $n^{\circ} 1.984$, November 2015). Here, we did not consider the pump and motor assembly's amperage, as well as the need for installation of a substation.

\section{Experiments}

\section{Analysis of efficiency and regional variations}

We applied three methodologies for the determination of the economic pipe diameter: (i) The equation of Bresse; (ii) Method Based on Pipe Weight (MBPW); and (iii) Method of the Linear Variation of Pipe Costs. The calculated diameters and their resulting costs were compared with the Method of Real Evaluation of Costs (MREC), which was applied to a wide range of commercial pipe diameters, with values similar to the ones calculated by the aforementioned methods, in a way to compare them and select the pipe diameter that implied in the lowest costs while attending to the limits of water velocity delimited by the technical norm NBR-12218 (ABNT, 1994).

This procedure allows to analysis the efficiency of each method in calculating the economic pipe diameter, as well as to quantify the exceeding costs resulting from the application of these methodologies. This procedure was then applied using base prices and inputs from five Brazilian states in order to analysis if there are regional differences associated to the efficient dimensioning of water distribution systems. The baseline value of costs for the 20 project conditions considered here was derived from MREC, with these standards, for each state considered.

\section{Analysis of the range of the parameter $k$ in Bresse's equation}

With the known pipe diameters that resulted in the lowest costs in each project condition, we also verified which values of $k$ in the equation of Bresse, in the range of 0.6 to 1.7 , resulted in these calculated diameters. Thus, we can analysis whether there is a range of variation for this parameter, common to all project conditions, that is efficient in the determination of the economic pipe diameter, and also quantify the associated additional costs in each case. We also assessed whether the size of the system and the material of which the pipe is made of influenced in this range of variation of this parameter.

\section{RESULTS AND DISCUSSION}

\section{Efficiency of the methodologies}

Table S1 (Appendix A1) shows the pipe diameters calculated by each methodology, for each project condition, for the price estimates of each of the five Brazilian states considered. For Alagoas, we notice that all three methodologies had difficulty in determining the correct economic pipe diameter in project conditions of large and small systems, being effective only in average conditions. The equation of Bresse is known to be able to correctly determine the economic pipe diameter for any condition, depending on an accurate value for $k$, however this variation will be discussed in the next section, and in the analysis here a mean of range of values presently used, $k=1.15$, was considered, which is also commonly employed by water system designers.

Besides AL, the same results were found for AM, DF, RS and SP, with all methodologies showing difficulty in estimating the economic pipe diameter accurately. However, MBPW was more effective in DF, RS and SP, miscalculating the diameter in only one of the 14 project conditions of small systems. We highlight that these states showed the highest piping costs, we could mean a higher sensitivity of this method to the input costs. For these states, the error of this method in the calculation for condition 5 resulted in a cost variation of 17,23 and $24 \%$, respectively, which is equivalent to additional yearly costs of approximately $\mathrm{R} \$ 10,000.00$.

For AL and AM, errors in dimensioning using MBPW in conditions 3 and 4 resulted in differences of 15 and $8 \%$ (condition 3) and 9 and 19\% (condition 4), respectively, which results in additional yearly costs up to $\mathrm{R} \$ 8,500.00$. Thus, this method is not recommended to be used in the dimensioning of the economic pipe size.

The equation of Bresse also did not accurately dimension the diameter for condition 2 for AL, DF, RS and SP, and conditions 2 and 4 for AM, however the resulting errors were over $50 \%$, reaching $109 \%$ for condition 2 , which corresponds to additional yearly costs of approximately $\mathrm{R} \$ 15,000.00$.

Regarding the determination of the economic pipe size with different inputs and services costs for each of the five states, we verified that there are differences in only two projects, meaning that the methodologies can be applied, without loss of performance, in any region. For project condition 4, in AL and AM the economic pipe diameter is $150 \mathrm{~mm}$, while in other states it is equal to $100 \mathrm{~mm}$. For condition 13, the economic pipe size is $200 \mathrm{~mm}$ for all states, with the exception of AM, where it is $300 \mathrm{~mm}$.

However, despite the impact the differences in energy power and input costs has on the total costs of these systems, we concluded that dimensioning of the economic pipe diameters is not very affected by regional variations.

\section{Range of variation of Bresse's equation's $k$ parameter}

By varying $k$ in Bresse's equation by 0.01 , in the range of 0.6 to 1.7 , we verified which intervals are effective in the determination of the economic pipe size in each of the 20 project 

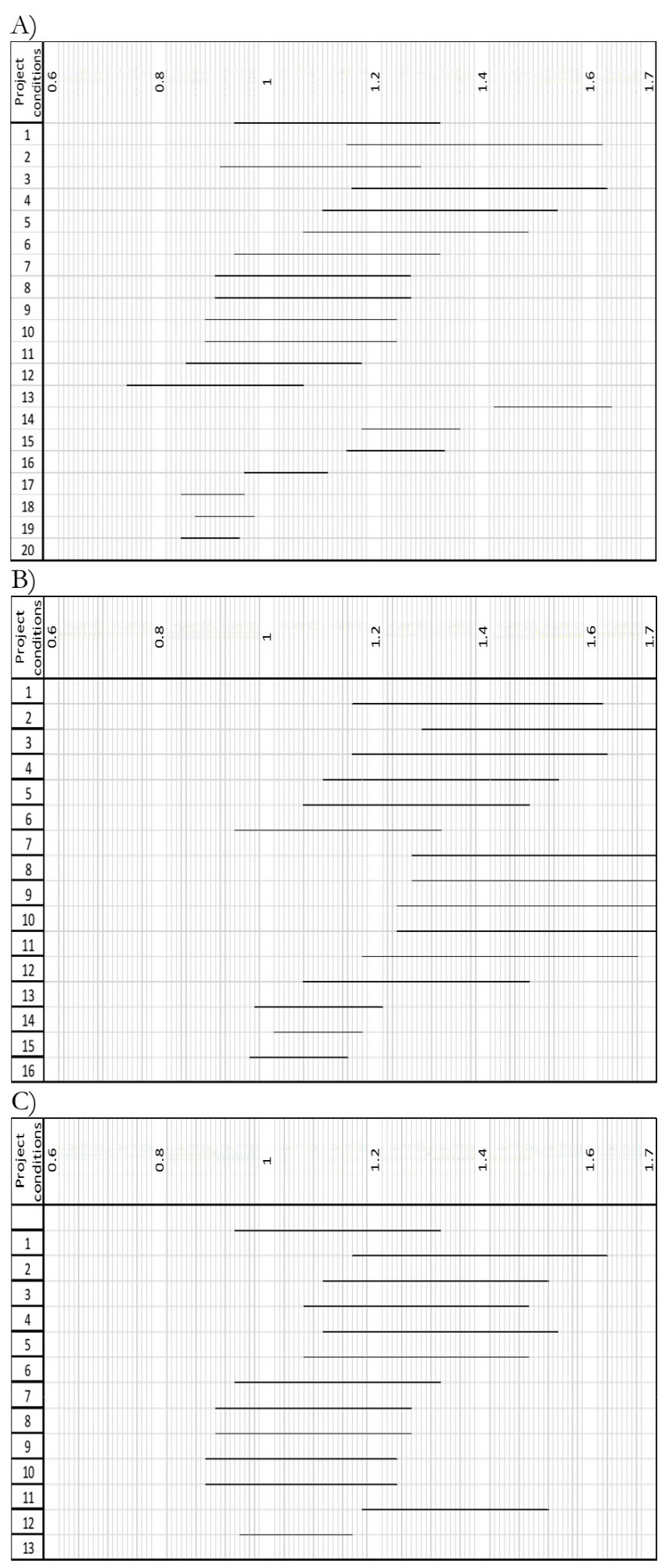

Figure 1. Effective intervals of variation of $\mathrm{k}$ for Alagoas, considering the costs of pipe made of (A) HDPE; (B) PVC DEFOFO; and (C) GFRP.

conditions. The diameters used as reference were calculated using MREC for the five states, considering pipes made of HDPE, and also considering the diameters, also calculated using MREC, of pipes made of PVC and PVC DEFOFO, with the costs for the state of Alagoas.
Considering the diameters calculated using MREC and pipes made of HDPE, a decrease in the range of the intervals is observed as the size of the systems increases. Between project conditions 1 to 13, with diameters up to $200 \mathrm{~mm}$, the extent of the effective intervals are reduced from 0.45 to 0.31 . This reduction is even more pronounced in project conditions with a diameter greater or equal to $400 \mathrm{~mm}$, in project condition 20 reducing the interval extent to only 0.09 .

For conditions with diameters less or equal to $150 \mathrm{~mm}$ (altogether, 12 project conditions), it is possible to determine a short interval, with $k$ ranging from 1.17 to 1.18 , where the economic pipe diameter is always accurately determined. These values of $k$ correspond to a flow velocity of approximately $0.93 \mathrm{~m} / \mathrm{s}$.

For larger systems, this range of values can result in additional costs, as for example for project condition 20, where the value of $k=1.17$ resulted in an increase of $38 \%$ in the yearly costs, or approximately $\mathrm{R} \$ 3,500,000.00$.

Figure 1 shows the range of values of $k$ where the equation of Bresse is effective in determining the diameter, for different project conditions and different materials. Thus, we considered that Bresse's equation showed the most consistent results and is the suggest methodology to be applied in the dimensioning of small water distribution systems, if a suitable value for $k$ is used.

When analyzing the variation in the intervals of effective $k$ values for PVC DEFOFO and GFRP, we noticed considerable displacement, meaning that the suitable values for this parameter are very dependable on the pipe material. For PVC DEFOFO, $k$ can range from 1.19 to 1.23 , and it is effective in determining the economic pipe diameter in 12 of the 13 project conditions analyzed. For this range of values, water velocity varies between 0.64 and $0.90 \mathrm{~m} / \mathrm{s}$, observing the velocity limits set by NBR-12218 (ABNT, 1994). By analyzing project condition 13, which has a diameter superior to $150 \mathrm{~mm}$, we notice that the interval is similar to what was found for HDPE, which suggests that the abovementioned range of values for $k$ can only be adopted for systems with diameters smaller or equal than $150 \mathrm{~mm}$.

Similarly, for GFRP, the intervals are also displaced, and for 13 of the 15 project conditions analyzed using this material, a range of values between 1.29 and 1.32 for $k$ can be used to accurately determine the economic pipe diameter. For this range of values, water velocity varies between 0.73 and $0.77 \mathrm{~m} / \mathrm{s}$, also observing the velocity limits set by NBR-12218 (ABNT, 1994).

\section{CONCLUSIONS}

We evaluated the most common methodologies employed for the dimensioning of the economic pipe diameter of water distribution systems, considering services and inputs costs for all five Brazilian regions. The main findings of our study were:

- MBPW, MLVPC and Bresse's equation, using an intermediate value for $k$ of 1.15 , could not accurately determine the economic pipe diameter for most project conditions;

- The variation of costs across the regions did not influence the efficiency of these three methods;

- In only 2 of the 20 project conditions analyzed here the variation of services and inputs costs caused by local differences changed the economic pipe diameters, which 
means that a unified methodology can be applied in the whole country;

- MBPW was slightly more accurate in calculating the economic pipe diameter of small water distribution systems. However, when it was inefficient, the resulting additional costs were high, and we suggest that this methodology should not be applied;

- The equation of Bresse, setting $k=1.15$, optimized all but one dimensioning for the states of AL, DF, RS and SP and two for AM. However, the resulting system costs differences were over $50 \%$, reaching up to $109 \%$, which shows that suitable values of $k$ have to be adopted;

- For the different pipe materials analyzed here, the range of suitable values of $k$ are reduced as the size of the distribution system increases;

- The range of suitable values of $k$ is also dependable on the pipe material. For HDPE and small systems, $k$ ranges from 1.17 to 1.18; for PVC DEFOFO, it ranges from 1.19 to 1.23 , and for GFRP, $k$ ranges from 1.29 to 1.32 .

Based on our findings, and mainly due to the high costs that result from inadequate dimensioning and the computational tools available nowadays, we recommend the application of MREC over the simplified methodologies discussed here for the dimensioning of economic pipe diameters, especially for large-sized water distribution systems.

\section{REFERENCES}

ABNT - ASSOCIAÇÃO BRASILEIRA DE NORMAS TÉCNICAS. NBR 12218: projeto de rede de distribuição de água para abastecimento público. Rio de Janeiro, 1994.

ALAGOAS. Companhia de Saneamento de Alagoas - CASAL. Edital no 18/2011, de 21 de novembro de 2011. Tomada de preço: contratação de empresa de engenharia para execução dos serviços no loteamento novo do Riacho Doce, em Riacho Doce, MaceióAL. Diário Oficial do Estado de Alagoas, Maceió, AL, 4 nov. 2011.

ALAGOAS. Companhia de Saneamento de Alagoas - CASAL. Edital no 16/2012, de 7 de dezembro de 2012. Tomada de preço: contratação de empresa de engenharia para realização dos serviços de ampliação do sistema de abastecimento de água, com melhorias da área do reservatório, do bairro de Rio Novo, em Maceió-AL. Diário Oficial do Estado de Alagoas, Maceió, AL, 22 nov. 2012.

ALAGOAS. Companhia de Saneamento de Alagoas - CASAL. Edital no 06/2016, de 19 de julho de 2016. Tomada de preço: contratação de empresa de engenharia civil, para executar serviços de implantação de sistema de abastecimento de água para os povoados Manteiga e Timbaúba, Batalha-AL. Diário Oficial do Estado de Alagoas, Maceió, AL, 28 jun. 2016.

ANEEL - AGÊNCIA NACIONAL DE ENERGIA ELÉTRICA. Resolução Homologatória no 1.984, de 10 de novembro de 2015. Tarifas de baixa tensão. Diário Oficial [da] República Federativa do Brasil, Brasília, DF, 13 nov. 2015.
AZEVEDO NETTO, J. M.; FERNÁNDEZ, M. F. Manual de bidráulica. 9. ed. São Paulo: Blucher, 2015.

BEDJAOUI, A.; ACHOUR, B.; BOUZIANE, M. T. Nouvelle approuche pour le calcul du diametre economique dans les conduites de refoulement. Courrier du Savoir, n. 6, p. 141-145, 2005.

BRESSE, J. A. C. Cours de mécanique appliquée: professé a l'École Imperiale des Ponts et Chaussées. Paris: Mallet-Bachelier, 1860. (Hydraulique, 2).

COHIDRO - COMPANHIA DE DESENVOLVIMENTO DE RECURSOS HÍDRICOS E IRRIGAÇÃO DE SERGIPE. Relatório de sintese do projeto: projeto de aproveitamento hidroagrícola do subsistema I - Maria Cristina I, Maria Cristina II, Maria Cristina III, e Areias do Moxotó. Aracaju, 2016a. v. 1.

COHIDRO - COMPANHIA DE DESENVOLVIMENTO DE RECURSOS HÍDRICOS E IRRIGAÇÃO DE SERGIPE. Relatório de sintese do projeto: projeto de aproveitamento d'água para consumo humano das comunidades Maria Cristina I, Maria Cristina II, Maria Cristina III, e Areias do Moxotó. Aracaju, 2016b. v. 1.

COHIDRO - COMPANHIA DE DESENVOLVIMENTO DE RECURSOS HÍDRICOS E IRRIGAÇÃO DE SERGIPE. Relatório de sintese do projeto: projeto de aproveitamento hidroagrícola do subsistema II - Comunidades CAU, Lagoa de Pedras e Moreira de Baixo. Aracaju, 2016c. v. 1.

COHIDRO - COMPANHIA DE DESENVOLVIMENTO DE RECURSOS HÍDRICOS E IRRIGAÇÃO DE SERGIPE. Relatório de sintese do projeto: projeto de aproveitamento d'água para consumo humano do subsistema II - Sítio CAU e povoados Moreira de Baixo e Lagoa das Pedras. Aracaju, 2016d. v. 1.

COHIDRO - COMPANHIA DE DESENVOLVIMENTO DE RECURSOS HÍDRICOS E IRRIGAÇÃO DE SERGIPE. Relatório de sintese do projeto: projeto de aproveitamento hidroagrícola do subsistema III - Comunidades de Alto dos Coelhos, Distrito Tingui e Sítio Joana. Aracaju, 2016e. v. 1.

DUPUIT, J. J. Traité théorique et pratique de la conduite et de la distribution des eaux. Paris: Carilian-Goeury, 1854. v. 1.

ENGENHARQ. Projeto para reforço do sistema de abastecimento d'água do município de Viçosa-AL. Maceió, 1999.

FREIRE, P. K. C. Estudo comparativo entre metodologias de dimensionamento econômico de adutoras. 2000. 140 f. Dissertação (Mestrado em Engenharia Civil) - Departamento de Engenharia Civil, Universidade Federal da Paraíba, Campina Grande, 2000.

GENIĆ, S. B.; JAĆIMOVIĆ, B. M.; GENIĆ, V. B. Economic optimization of pipe diameter for complete turbulence. Energy and Building, v. 45, p. 335-338, 2012. http://dx.doi.org/10.1016/j. enbuild.2011.10.054.

GUIMARÃES, F. F. C. Caracterização do diâmetro econômico de recalque considerando-se tubulações de RPVC. 2009. 15 f. Monografia 
(Graduação em Engenharia Civil) - Universidade Católica do Salvador, Salvador, 2009.

MELZER, A. Sur le diamètre économique d'une conduite de refoulement. Liège: Centre Belge d'étude et Documentation dês Eaux, 1964.

MENDILUCE, E. Cálculo de lãs tuberías de impulsión. Revista de Obras Públicas, 1966.

TALAVERA, S. T. La verdadera fórmula de Bresse. Manágua, Nicarágua: [s.n.], 2014. Available from: < https://pt.scribd.com/ doc/226040340/La-Verdadera-Formula-de-Bresse-15-02-2014>. Access on: 29 aug. 2018>.

\section{Authors contributions}

Cléber Henrique de Araújo Gama: Data acquisition, performed the analytic calculation, performed the numerical simulations, took the lead in writing the manuscript, discussed the results and review.

Vladimir Caramori Borges de Souza: Conceived of the presented idea, developed the theory, review, discussed the results and contributed to the final manuscript.

Nélia Henriques Callado: Conceived of the presented idea and review. 
Appendix A1. Summary of all diameters calculated by three differents methods.

Table S1. Diameters calculated by each method for each of the five Brazilian regions, for pipes made of HDPE. The shaded values are the calculated pipe diameters that differ from the value that resulted in the lowest costs, while the remaining values are the ones that met the economic pipe diameter calculated by MREC. Q is the project $(\mathrm{N})$ flow and $\mathrm{L}$ is the size of the system, in meters.

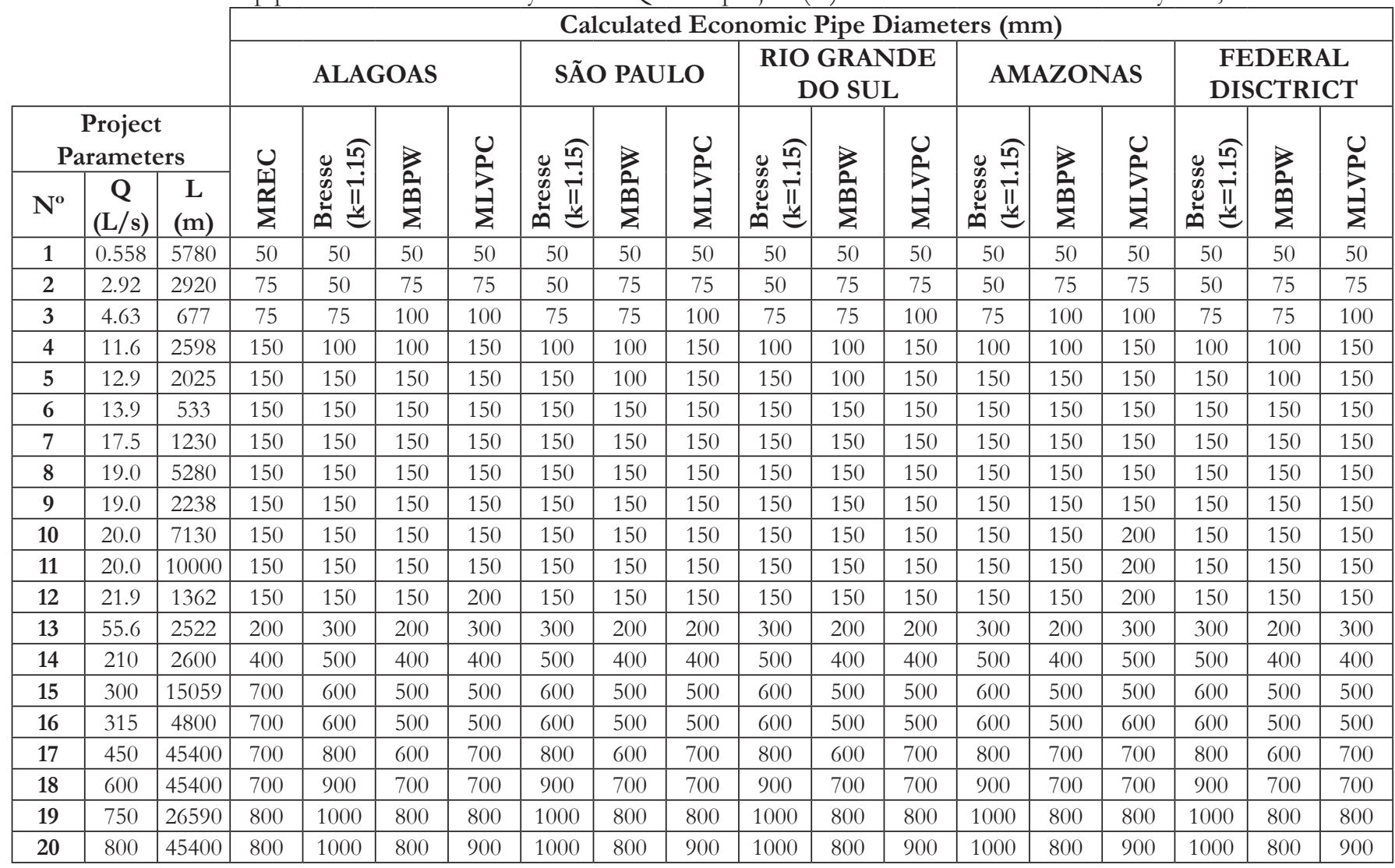

